(昭和 25 年 2 月 28 日受理)

\title{
試作メリヤス川脖擦試驗機について
}

\section{慗京工䅈大學 細四一夫西川登塚越秀也}

\section{1. 緒言}

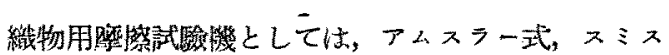
式，ショッパ-式等㮔々の型式のbのがあるが，メリ

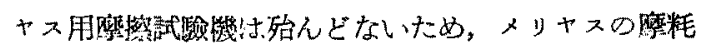

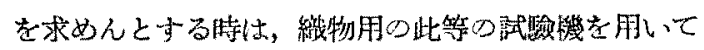

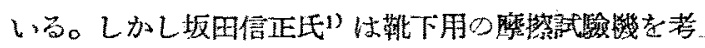
案されてをり，又沾國の Nottingham 大學の.W.

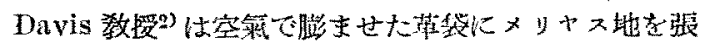
ク，之を一定の織物（綃毛織物）て摩接する方法を器 表されている。

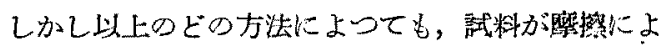
つて破燷するる迄の回數で，その摩耗度を比較するか，

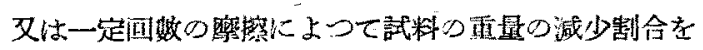
比較するか，或は一定回數の摩攃後に於てその强力の 減少の㑷を比校するか等の方法によつているため,

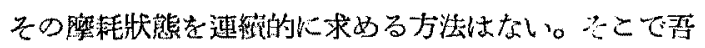
吾は以下の上万な方法によつて連維的にその䐴耗を求 めることの出來る試驗挠を考穼したので荡る。

\section{2. 試驗機の構造}

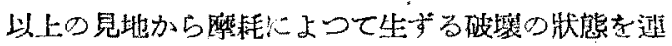

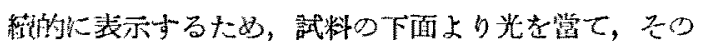

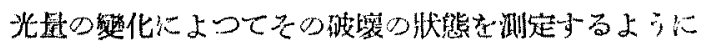

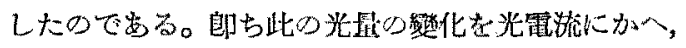

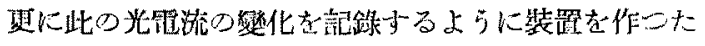
のをむる。

主要部分。楼落

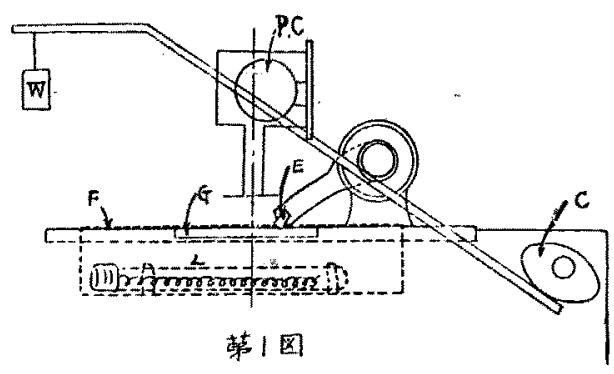

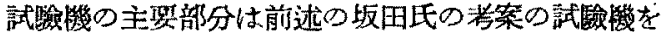

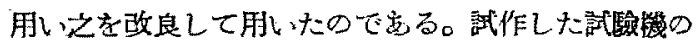
主姴部分の權造は第 1 圆の如くですつて，圆中のFは 試料， 【はランプ，PC は光雪管， $\mathrm{G}$ はガラス板， $\mathrm{E}$

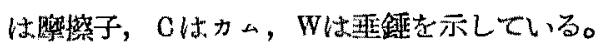

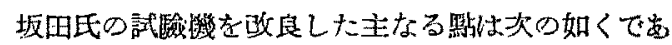
る。

\section{1). 停止裝圈の除去}

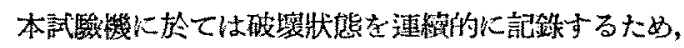

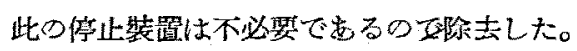

\section{2) 摺動板の改辰}

試料の下面より光を照射して，その光を唀過させる 必姴があるため×ボナイト板の代りに，スリガラス板 を空にもつた光源箱を裝唯して，その上に試料を裝置 Lた。

\section{3）光電管の裝着}

光源箱と相對して光雷管を裝照して，下方のランプ より照射される光を提へた。此の際光源からの光䝿を 一定にするために巾 $3 \mathrm{~mm}$ 是さ $33 \mathrm{~mm}$ のスリットを

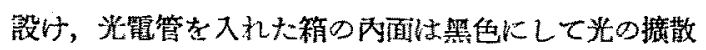
を防儿怔。

\section{4）記錄装䁌の装着}

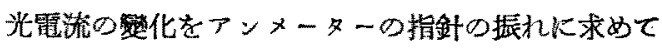

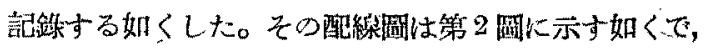

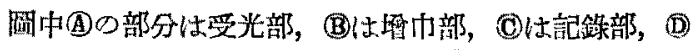

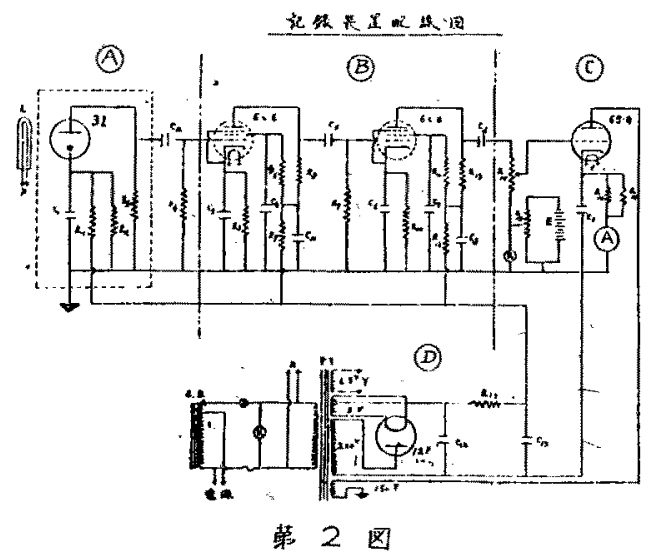


は霓源部にある。

その䛧の部分は，坂田氏の詿驗嘰をそのま〉健用し た。

\section{3. 測定方法}

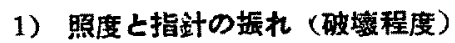

一定面程の孔より入る北最の照度とその時のアンメ ーヌーの指針の振れとの關係を求めた。即ち第 3 圆の 如くである。

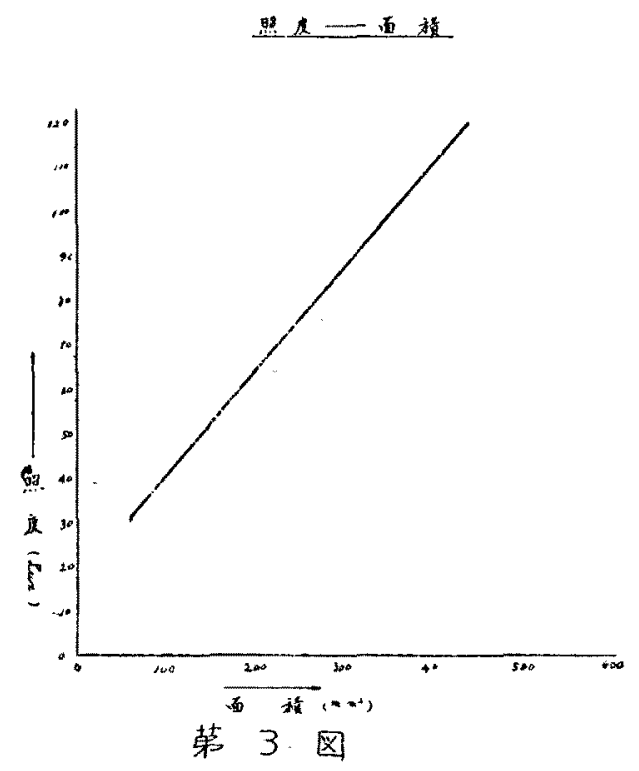

\section{2) 慗子の加筮}

摩摽はその摩擦子に加へる贆力に上つて異るため常 に一定の㗨力を與えて测定することが必姴で京るが， $1.0 \mathrm{~kg} / \mathrm{cm}^{2}$ の力を加へて試料を䐴掽するのか゚適賞と思 へたので，此の大さによつた。

\section{3) 䨙擦子の移動}

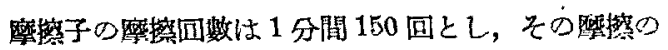
距離は $3 \mathrm{~cm}$ と乙，往動に於てのみ摩热子を譈かせ， 復動仙カムよよて作㲜しないように裝置した。

\section{4) 光 源}

試料の下面より照射するために用いた雷灯は $100 \mathrm{~V}$ $20 \mathrm{~W}$ の細長い、電球を用い，とれを上部に $49 \times 95 \mathrm{~mm}^{2}$ のスリガラスの究を有する箱の中に入れた。

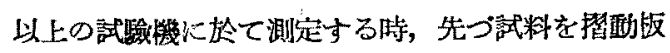
に正しく裝着して，光源からの光量を光雷管が捉へて 生ずる光電流を一定にし，フンメーターの指釬を零默 に合せ，起動して摩擦子を作媑せしめる。摩擦の淮行
に伴いアンメーターの指針の振れが大となる。此の指

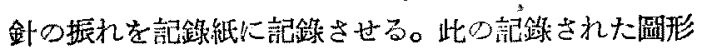
の面積を第 3 圖によつて試料の破壊の大さを求める。

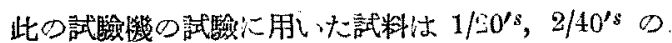

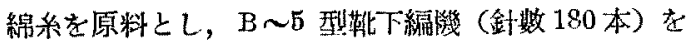

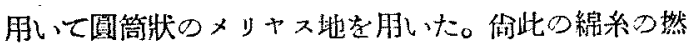
数を種ふにが、て試料を作つた。

\section{4. 測定結果}

前記の方法によ二て試驗を行つた結罢け第 4 圆のよ うな曲線が得られ，乙れを第 3 固から各回数に於ける

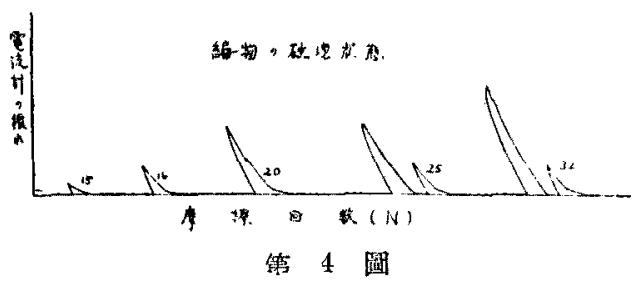

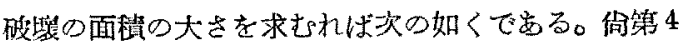
圆の摩擦回数 25 及 30 国儿就いて，2 個の曲線が得ら れているが，之は往動に於けるれの大さと復乘に於け るれの大さが買るために生したもので，往㡖に於て示 した曲線上り孔の大さを求めて比較したのでるる。

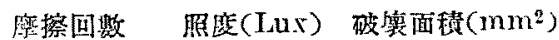

$\begin{array}{rrr}20 & 26.5 & 43 \\ 25 & 31.0 & 64 \\ 32 & 41.5 & 108\end{array}$

之等の關係より第 5 關に示すような關係曲線が得ら れる。

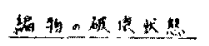

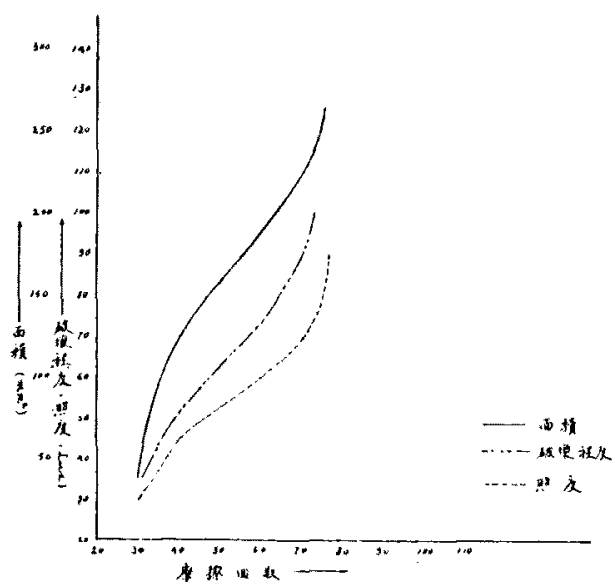

第 5 图 


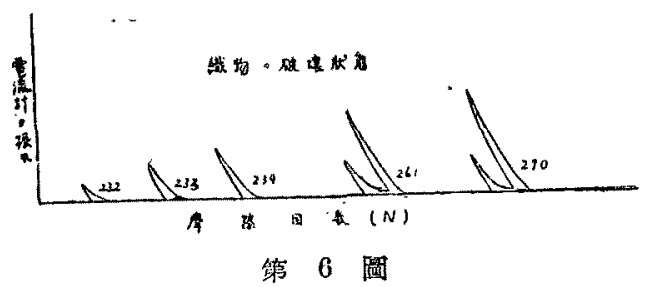

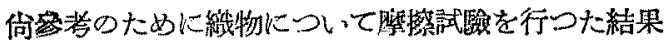
は第 6 副に示すようで出つて，編物の場合よりも判然 とした址線が得られた。郎ち織物のように小さい力で

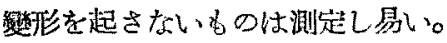

\section{5. 結論}

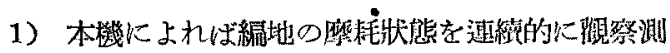

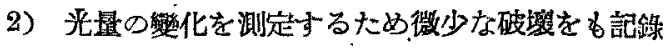
するととが出來る。

3）織物の武驗にむ使用寸るととが可能であり，編 物の場合よりもはつきりとその破壤狀態を觀察湘定出 來る。

\section{女 献}

1）坂田信正（繊工婄 1,1936 )

2) W. Davis J. Text. Inst.: 'T 200. 27, 1934.

附 記

本研究を行らに當り，日本大學工學部山本氏及び肉

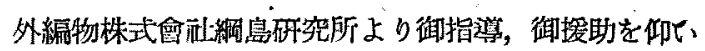
仡ことに對し深甚の謝意を表する。份昭和123年 5 月本 覦春期研究發表會に於て辣演したものでる。

定することが蝶來る。

（昭耓25年 8 月 13 日受斑）

\begin{abstract}
紱物の膘擦試驗に關する研究
\end{abstract}

\title{
第 2 報 耐摩耗曲線の表示と比較法について
}

$\begin{array}{lllll}\text { 東京工業大學 } & \text { 青 } & \text { 木 } & \text { 的 } \\ \text { 岐㚖短期大學 } & \text { 村 濑 春 彌 }\end{array}$

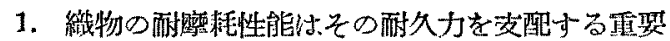

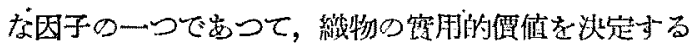

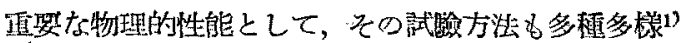
でする。一般に耐照耗性能の表示方法として探用され ているのは，所謂耐擦耗曲線を以てするか，或は相擦

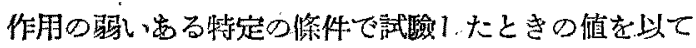
するかの何れがでる。この何れの場合でも湘定值は その材料特有の政䇮を示し，特炇前者の方法で 2 種以 上の材料の比恔を行うよ弓な場合には，測定值の散䍃 を忿頭に扣かないと誤つた結䄖を下す传险がないとは 云えないったとえば，測定做の散销の程度によつては，

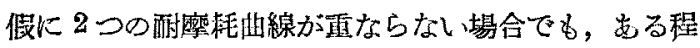
应近接していると，察際に差がないのにもかわわらず 差があるとしたりする危險がある。

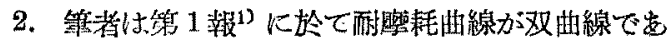
らわされるととを示した。其他研究，たと文ば， R. G. Stoll, 正田藩夫氏等の研究》に括いてもそちで

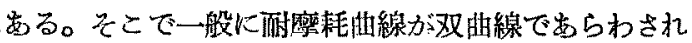
るとしよう。

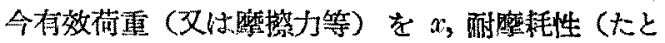

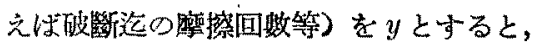

$$
\dot{y}=a x^{\beta}
$$

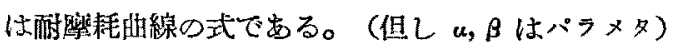

然し惯際儿は蹎の值 $a, \beta$ は末知であるので，n個の $x$ ，について $y$ を测定し，最小自乘法によつて $a, \beta$ の 推定值 $a, b$ を求める。:この場合從來の方法と異なる のは，我及の推定した曲線がよく賞筷まるかどうが 社檢定によつて確かめることでする。そして更に任 意の $x$ に對する $y$ の分散 $\sigma_{y}$ を求め，土1.96 $a_{y}$ の幅

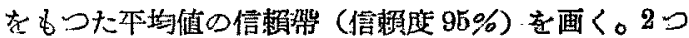

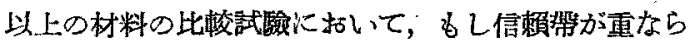
なければ，有意な差があるするのである。（とのよ らな方法の一般理諭については W. E. Deming2) が 既に述べている。）赎では說明の便宜上，スミス型試 